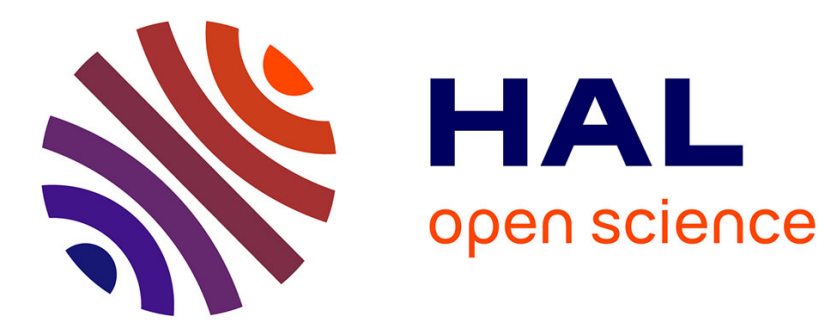

\title{
Passion Love, Masculine Rivalry and Arabic Poetry in Mauritania
}

\author{
Corinne Fortier
}

\section{To cite this version:}

Corinne Fortier. Passion Love, Masculine Rivalry and Arabic Poetry in Mauritania. International Handbook of Love. Transcultural and transdisciplinary perspectives, pp.769 - 788, 2021, 10.1007/9783-030-45996-3_41. hal-03245591

\section{HAL Id: hal-03245591 \\ https://hal.science/hal-03245591}

Submitted on 25 Jun 2021

HAL is a multi-disciplinary open access archive for the deposit and dissemination of scientific research documents, whether they are published or not. The documents may come from teaching and research institutions in France or abroad, or from public or private research centers.
L'archive ouverte pluridisciplinaire HAL, est destinée au dépôt et à la diffusion de documents scientifiques de niveau recherche, publiés ou non, émanant des établissements d'enseignement et de recherche français ou étrangers, des laboratoires publics ou privés. 


\title{
Chapter 41 \\ Passion Love, Masculine Rivalry \\ and Arabic Poetry in Mauritania
}

\author{
Corinne Fortier
}

\begin{abstract}
Love was not born in the West during the twelfth century: the pre-Islamic Arabic poetry of the sixth century testifies to its existence in the ancient Arab world. These poems are well-known among Moors-the population in Mauritania who speaks an Arabic dialect called Hassāniyya-and inspire the local poetic forms. Unlike numerous traditions, poetic inspiration of Moorish poets is not spiritual but carnal because it takes root in the desire for a woman, who taste like Baudelaire's Fleurs du Mal. Love poems in Mauritania are not the privilege of a handful, they are primaly composed with the aim of reaching the woman's heart, like bedouin pre-islamic poetry. So her first name, her body, her qualities and defects, from erotized become poetized.

In the Moorish society of Mauritania, the sphere of seduction and passion, very often poetized, coexists in parallel with the marital sphere. It is thus never his wife to whom the poet addresses his poetry but another woman that he desires. The lover's figure is a feminized figure, because he can no longer control himself and is subject to a passion that is annihilating him. However, even when the man is in this state in the seduction phase, marked negatively with passivity and suffering, it is only a temporary situation that represents minor harm on the way to conquering the woman and gaining a dominant position over other men. Courtship has commonly been a male prerogative, while women are often not supposed to manifest their desires except in an indirect way. The fact that the man is considered the desiring subject and the woman the desired object is a major cross-cultural gendered element which justifies men's appropriation of women's bodies.
\end{abstract}

Keywords Love · Mauritania · Baudelaire · Passion · Courtship · Gender · Poetry · Arabic pre-islamic poetry

C. Fortier $(\bowtie)$

French National Center of Scientific Research (CNRS), Social Anthropology Lab

(Collège de France), Paris, France

e-mail: corinne.fortier@ college-de-france.fr 


\subsection{Introduction: Love Beyond the West}

Love and especially passion love was not born in the West during the twelfth century, as Denis de Rougemont (1972) contends: the pre-Islamic Arabic poetry of the sixth century testifies to its existence in the ancient Arab World. These poems are known among Moors of Mauritania and inspire the local poetic forms. They are well-known because most Moors can understand their literal Arabic. These poems of Bedouins in the Arabian desert find a particular echo among the nomads of the Sahara, as they evoke the tent, the encampment, the desert, the tribe, the veiled women ${ }^{1}$ wearing henna and ankle bracelets (khalkhāl); all Bedouin realia which are familiar to Moors. Moors population of Mauritania speaks an Arabic dialect, Hassāniyya, and self-identifies as bidān or 'white people', to distinguish themselves from südān or 'black people'. In Mauritania, alongside the arabophone Moorish society, one finds Halpulaaren, Soninke and Wolof communities.

Moorish society in Mauritania is well known in the Arab world as a society of a million poets (Taleb-Khyar, 2001). Poetry is very common in this society because poetry is inseparable from love affairs. Unlike numerous traditions, poetic inspiration of Moorish poets is not spiritual but carnal because it takes root in the desire for a woman, who taste like Baudelaire's Fleurs du Mal (Flowers of Evil). Indeed this poetry, through the archetypal situations it describes, of which I give account in this chapter, reveals the models that shape the gender roles when it comes to love relations.

However, the topic of love, is often neglected in anthropological research, especially on Arab countries. For instance, there is much research on male domination, female agency, and their relation to religious and social norms, but despite its importance in the performance of gender, little has been written on the complex role of love. This absence is especially striking given the fact that in both the present and the past love has been a major preoccupation in the lives of people of the region, as elsewhere, and is well-documented in poetry. Anthropology seems particularly suited to the study of intimate experiences through its focus on practice and everyday discourse.

Indeed, this anthropological research is based on intensive fieldwork in different regions of Mauritania, in the desert (bādiyya) and in the capital city Nouakchott, from 1996 to 2018, living with families and interacting with both men and women of different ages, social statuses, and tribal origins. The love poems quoted in this article were collected during this long fieldwork and translated by the author. They were selected because they afford deep insights into intimacy of Moorish society regarding passion love, and gender relations.

\footnotetext{
${ }^{1}$ On the topic of veil in Islam and in Muslims societies, see Corinne Fortier (2017c).
} 


\subsection{History of Love in Anthropology}

For a long time, the study of kinship in anthropology overshadowed interest in personal sentiment. As long as the study of structures and functions prevailed, individual feelings such as love had only a minor role in research. A few exceptions concern the Pacific islands, which are places that nourished Western love fantasies since the start of their exploration by Europeans in the eighteenth century. The most prominent example in this regard is Margaret Mead's work on the Samoa Islands (1966) from the 1920s (Tcherkézoff, 2004).

If we consider larger trends in anthropology, it is possible to broadly distinguish three main approaches to contemporary studies of love. The first, based mostly on comparative surveys of cultures and rooting its understanding of emotions in biology, emphasizes the universality of the feelings associated with love. William Jankowiak is probably the most famous proponent of this approach. In a study that he coauthored, he argues for instance that the basic emotions related to love are universal, mostly due to hormonal reactions, but shows that the romantic kiss is recorded in less than half of his global sample of cultures (Jankowiak \& Fischer, 1992; Jankowiak, Volsche, \& Garcia, 2015, see Jankowiak's chapters in this book).

The second trend, among whose main proponents in anthropology is Charles Lindholm, studies love as an outcome of structural features in the organisation of societies (Lindholm, 1988, 2006). Similarly basing his research on a comparative survey of cultures, Lindholm argues that there are three types of society that favour romantic love: hierarchically rigid societies with a strong kinship system, in which people see love relations as an escape from social constraints and as such, incompatible with marriage; fluid societies, in which people try to combine passion love with marriage; and societies in which young people are given the freedom to experiment with romantic love until they reach a certain age, but are sooner or later pulled back into a rigid kinship system. Lindholm's notion of fluidity is reminiscent of sociological theories that consider love an outcome of systemic features of European and North American capitalism (Giddens, 1992; Illouz, 1997).

The third trend considers love in its current shape as primarily a European and North-American cultural product and studies the circulation of this model around the world. A large body of research addresses the impact of love on kinship arrangements (Cole \& Lynn, 2009; Hirsch \& Wardlow, 2006; Lipset, 2004; Padilla, 2007; Pettier, 2016; Stacey, 2011; Zavoretti, 2013). In her pioneering research on love letters in a rural area of Nepal Laura Ahearn contends, for instance, that romantic feelings, earlier related to shame, had become a symbol of modernity for the villagers she studied (Ahearn, 2003, 2004). They started to dream of love affairs resembling those they saw in Indian and Nepali films, textbooks and magazines, and to conceive marriage as successful if based on a companionate relationship in accordance with the model promoted by development programs.

The three approaches that we analytically distinguish here have their strengths and downsides. The approach based on the universality of certain biological reactions, while acknowledging the importance of love outside Europe and North 
America, falls short of explaining the diversity of discourses and practices concerning attraction and desire that can be found around the world.

\subsection{Two Kinds of Love}

Among Moors in Mauritania the sphere of seduction and passion, very often poetized, coexists in parallel with the marital sphere governed by Muslim jurisprudence ( fiqh). Masculine love poetry arises from a man's unsatisfied desire of for a woman. It is thus never his wife to whom he addresses his poetry but another woman that he desires. As elsewhere, Moorish men initiate extramarital affairs more frequently that women because expressing their desires freely is socially much more acceptable for them than it is for women. As for feminine love poetry (tabra), it circulates only among women, modesty preventing them publicly displaying their desire for men.

Among Moors two kinds of love coexist: love for wives and love for mistresses. The first is a marital feeling which develops within the framework of conjugal relationships; the second, passionate love, is exclusive to mistresses. Passion is forbidden, while marital love is licit. The first belongs to the domain of pleasure and immediacy, while the second involves a sense of duty and its duration over time. These two kinds of love are evoked in a poem using the metaphor of water, which is particularly significant in a desert region where it is an invaluable resource. The poem refers to a married man who goes on a journey with goatskins full of water. On his way, as a flash of lightning announces torrential rain he pours the water out of his goatskins. The flash of lightning represents love for a woman at a first sight, and the rain falling is the image of the passion which makes the man abandon his reserves of water, symbolic of the marital relationship. It shows that the idea of love at first sight is not only a Western idea, as some historians such as Jean-Claude Bologne claim, because we can track it in classical Arabic poetry.

For a long time, it was rather unusual for anthropologists to reveal the hors champ of passionate love especially in the "Muslim word" (Fortier, 2018a). They preferred to focus on the alliance system, neglecting extramarital relationships occurring before, during or after married life. Until the 1980s, anthropologists of the Middle East were interested mainly in kinship, with a special focus on the specificities of the so called 'Arab marriage' between parallel patrilateral cousins, in many cases without taking into consideration the sentiments involved (Fortier, 2018b). Research on kinship explore also the concepts of 'honor and shame' as a key to the social and cultural systems in the Mediterranean area. Another important line of inquiry into topics related to love in the Arab world was that of Islamic law (Fortier, Kreil, \& Maffi, 2018).

In the 1980s scholarly interest in emotions, personal agency and later the transnational circulation of imaginaries began to grow. Starting in the 1980s, new developments in anthropology paved the way for the integration of love into the study of Arab countries (Fortier, Kreil, \& Maffi, 2016). The anthropology of 
emotions gained increased significance in the United States (Lutz \& Abu-Lughod, 1990; Lutz \& White, 1986). This attention to subjective experience set the conditions for the anthropology of love to take off in the first decade of the twenty-first century.

Concerning the Arab world, Lila Abu-Lughod's 1986 book played an important role in anchoring the topic in research. In her analysis of poetic genres among the Awlād Alī Bedouins of North-Western Egypt, she shows how poetry praising honour was used in parallel with poetry expressing desire and torment, sometimes contradicting kinship rules (Abu-Lughod, 1986).

However, even if they are rarely an object of study, extramarital relationships are not uncommon in many societies, at least among Moors (Fortier, 2004a). Pastoral nomadism, as well as men's frequent travel for commercial or political purposes, favour them. Nowadays the relative anonymity of contemporary cities also provides a perfect setting for such affairs. Such relations are not even taboo among Moors, as they are in other places around the Mediterranean area and North Africa. These meetings, while illicit from a religious point of view, are socially tolerated as long as they remain discreet.

\subsubsection{Courtly Love}

Moors have inherited a specific Arabic dialect, Hassāniyya, from the Arab populations (Ban̄̄ Hassān) present in the country since the fourteenth century, and a courtesy code inspired by ancient Arab chivalry or futūwwa. ${ }^{2}$ Some historians (Von Hammer-Purgstall, 1849) even hypothesize that Arab chivalry pre-existed European chivalry and influenced it. This courtesy code is very similar to that which appeared in the West during the Middle Ages. The similarity is in the 'common medieval cultures which can be found, in broad terms in both the Christian West and the Muslim East' (Zakeri, 1996, 32). The courtesy code does not contradict Islamic values, which have been present in the region for a long time. ${ }^{3}$

As in the thirteenth century in France, the courtesy code represents a social distinction which differentiates the 'courteous' or the 'courtier', from the villain (Duby, 1981). The courtesy code is still alive among Moors, despite the rise of the individualism and the influence of a certain Islamist discourse (Ould Ahmed Salem, 2013), and a man cannot diverge from this code without losing his honour.

The noble man devotes himself to the 'game' of love as he devotes himself to the 'game' of war, both being a form of challenge. The means used to conquer the woman are similar to techniques of hunting and borrow their vocabulary from warriors' and hunters' language. The woman is prey, a gazelle, according to the classical Moorish and Arabic poetic image which is still contemporary, an object of

\footnotetext{
${ }^{2}$ See Farès (1932) and Vadet (1968) on the Arabic notion of futūwwa.

${ }^{3}$ In West and North Africa Islam was present even before the Maliki Islamic school of jurisprudence introduced during the eleventh century by the Almoravids (Berbers).
} 
envy which men try to capture as a precious trophy. Thus, women are not much considered for themselves but appear rather as assets in the competition between men. The courtesy context which seems to glorify women in fact essentially highlights the rivalry between men. Seduction represents more than the courting of women: it is a way to perfect male qualities, as in the fin amor (Duby, 1988, 47; Baladier, 1999, 82). Thus the 'game of love' is an initiation process, because it is through mastering it that young men acquire self-control (hkam rāsu), a virtue also known in the Medieval West under the name of mezura (Wettstein, 1945).

\subsubsection{Night Meetings}

Seduction is a rite of passage in which young men compete with other pretenders. One of their favourite settings is late meetings, when in the cool of the night they improvise poems in honour of the attending girls. Men engage in night meetings from puberty, or, according to the local expression, as soon '[the boy] has worn sarouel trousers and fasted for Ramadan' (rbat sarwāl u șām ramad̄ān) at around 12 years of age. For girls it can start very young, at around the age of nine (Fortier, 1998). This type of courtly meeting, similar to that known to Tuaregs by the name ahal, is locally given the Arabic term 'night assembly' ( jamá 'at al-layl). They begin after the night prayers and go on until very late. They generally take place far from houses, on moonlit sand dunes. Such an atmosphere can stimulate the participants' poetic inspiration. These evenings are always accompanied by music ( $h a w l$ ) which resounds in the night's silence. It usually consists of a rhythm on a small hand drum (tbal) played by one of the girls and the sound of a griot's lute (tidinit) or the harp (ardin) of a griotte.

The rivalry between young men appears in the declamation of the most beautiful quatrain $(g \bar{a} f)$, to the woman they wants to court. Ghazal refers to a straightforward type of poetry related to flirting. The ghazal is an arabic form of poetry from the sixth century (Blachère, 1975). The word ghazal itself derives from the verb ghazala, meaning 'courting' (ibid). The ghazal, the more popular form of poetry among Moors, generally takes the shape of a quatrain $(g \bar{a} f)$, and is essentially composed with the aim of reaching the heart of the beloved.

The competitor will increase the difficulty by composing on the same rhyme as its predecessor a longer poem that will become a septan called tal' $a$. This term, which means to climb, refers to the fact that the poet develops the quatrain: tal 'a al-gâaf. A poem always begins with a $g \bar{a} f$, which is developed in $t a l^{\prime} a$. This poetic rivalry may lead to a satirical poetic game called $g t \bar{a}$ '. This Arabic term means to cut and in this case refers to rivalry, although it is only a verbal duel. Whoever turns out to be the strongest at this poetic tournament has a good chance of gaining the attention of the beloved woman. In love, the poetic duel is similar to the Western Middle Ages tournament since it aims to reach the heart of a woman by means of verses similar to arrows. 
To please the young women the men do not spare their poetic eloquence, as shown in this quatrain $(g \bar{a} f)$ :

It is my seventh verse ( $g \bar{a} f)$ since the beginning of the evening, and when my beloved deigns to smile/I shall improvise the eighth and the ninth, the tenth and the eleventh (...).

Women who have been honoured with poems can acquire a reputation beyond the assembled circle. Among those who 'arouse the duel' (labrāz) at the night meetings, some will become 'shabībāt'. This term, built on the same Arabic root as shabāb, youth, is used for a woman whose name is praised by all; in this respect being quoted in poems which will remain in the oral memory is a great acknowledgment for a woman.

\subsection{Nostalgic Poetry}

Men appear in Moorish poetry as devoted admirers of women in a tone similar to that of Arabic pre-Islamic poetry and Medieval Occitan madrigals, which mostly describe the woman as a mistress of whom the poet is the devoted slave (Lavaud $\&$ Nelli, 2000). There has been a strong link between Mauritanian courtly love and the Arab Bedouin tradition since pre-Islamic times. Two types of love poetry circulating among Moorish men are inspired by two types of Arabic love poetry: the $n a s \bar{\imath} b$ and the ghazal. The first traces of these two styles go back to the sixth or seventh century.

Some link the term nasīb to the Arabic verb nasaba, meaning 'to sing of a lady's beauty and the trouble she inspires' (Blachère, 1975). The nasīb has a nostalgic style, evoking places haunted by women and the delicious pangs they provoke. The poet sings of the absence of his beloved, identifying her with the place where he met her. The nostalgique tone of Bedouin poetry, in which the poet depicts the vestiges (dune, tree) of the past, is suggested in Arabic by the periphrase: 'To stop or to cry on the remains of the past' (al-wuqūf 'ala 'al-ațlāl or al-buk' al-ațlāl).

The definition of gratitude (1995: 186) of the french philosopher André CompteSponville applies perfectly to this specific form of poetry:

It is this joy of memory, the love of the past or the suffering of whas does not longer exist, not the regret of what did not happen, but the joyful memory of what happened.

The soul of Moorish poetry would hold in this adage of Epicure: 'Sweet is the memory of the disappeared friend', a bittersweet feeling found in many poetic and musical traditions throughout the world.

An archetypal phrase expresses the suffering provoked by the beloved's absence: 'I am languishing with love for you' (mitwahashak). This expression derives from the Arabic term wahsha, which means to languish, commonly used in Hassāniyya. This notion which refers to nostalgia is similar to the Baudelairian spleen, an English term wich refers to the organ of spleen. It is also close to the Portuguese saudade, an expression first used by the troubadour D. Sancho, and which was probably inspired 
by the courteous Arab ideal (Demeuldre, 2004, 10) as indicated by the Arabic etymology of this term, sawdā', which designates the atrabile. The term of melancholy in French, derived from the Latin melancholia which derives itself from the Greek mélas khôlé: black bile. These various expressions have in common to establish a relation between a particular psychological state marked by languor and one of the moods of the body, in this case the black or atrabile mood, in conformity with the humoral theory of hippocratic origin well-known in the West but also in Arabic and Moorish medicine (Fortier, 2017a, b, c).

\subsection{The Landscape of Love}

The decisive moment of the meeting is fatal for a man. As Gilles Deleuze affirms:

I do not desire a woman, I also desire a landscape that is enveloped in this woman, a landscape that, if necessary, I do not know and I feel and until I have unrolled the landscape that she envelops, I will not be happy, that my desire will not be fulfilled, my desire will remain dissatisfied. ${ }^{4}$

A Moorish poet was charmed by a beautiful woman despite, and perhaps because of, the dangerous omens that surround the circumstances of her meeting. To speak of the fig-tree of hell with which he noticed it at the hottest hour of the day, is ready to give way to his perishment which he fears and hopes. It is an indirect process, sometimes used in Moorish poetry, to say the ardour of the passion by a detour that evokes its circumstantial aspects, time and space:

Yesterday at the time of the nap/I saw the one I was dreaming of under a shrub of $\bar{a} t i l^{5} /$ next to a fig-tree of hell.

The landscape of love is also important in the poem of Charles Baudelaire, 'To a Creole Lady' (1975, 62), where the evocation of the atmosphere of Port-Saint-Louis on Mauritius island is merged with the languorous souvenir of Madame Autard de Bragard:

In the perfumed country which the sun caresses, I knew, under a canopy of crimson trees, And palms from which indolence rains into your eyes, A Creole lady whose charms were unknown.

\footnotetext{
${ }^{4}$ Deleuze-Abécédaire-D Comme désir: https://www.youtube.com/watch?v=03YWWrKoI5A

${ }^{5}$ The scientific name of this tree is Maerua crassifolia.
} 


\subsection{The Uniqueness of the Beloved Woman}

In anti-Islamic Arab romantic poetry the name of the beloved woman is often quoted. The poet Qays ibn al-Mullawah is more well-known under the name 'the fool of Layla' (majnün Layla) by reference for the woman for who he composed poems. This association between the name of the poet and the first name of his muse is also found in some French poets: Aragon is inseparable from Elsa, Lou from Apollinaire.

The woman's name is also the object of love in Moorish poetry. A Moorish poet, obsessed with the souvenir of Mana, cannot hear a word beginning with the initial of her first name, without thinking of her:

Every time I hear a word beginning with M/I immediately think of Mana.

The poet's inspiration comes from his attraction to a woman whose beauty is usually praised in his poems. According to the sublimation process inherent to creation, the erotic parts of the woman's body are described in the poems. This Moorish poetry is similar to the west form of poetry named 'blazon', from the Middle Age and codified during the Renaissance, which praises some elements of woman body. If the charms of the beloved are honored by the poets, they have also glorified her defects in an affective way.

It is the most beautiful declaration of love that a man can make to a woman that to express his love to her in spite of her defects. It shows that the woman is not considered as an ideal or a perfect woman, or an object of 'crystallization'. The concept of crystallization was created by the French novelist Stendhal (1783-1842): 'What I call crystallization is the operation of the mind, which draws from all that is presented the discovery that the loved object has new perfections' (Dictionnaire Petit Robert 1990, 425). The poet is in love with a singular and imperfect woman, loving her the way she is, whatever her imperfections. As this Moorish poem summarizes, it is a matter of gaze:

They saw the ugliness of the woman who is at the origin of my pains

We have all the same pupil but not the same gaze.

\subsection{The Pain of Love}

Love poems express the pathos of the passion with its distress, suffering and fury. For example, a poet describes the beloved as well as the pains and the joys which she arouses in him in the following verse:

When she was tinged with henna, the one that I love

Suffering appears which was not in me. 
In the Moorish society, the man is enthralled by the woman: he becomes blind, he loses his mind or his heart (galb), ${ }^{6}$ she cuts his heart to pieces (qta ti galb $\left.\bar{\imath}\right)$, he is possessed by her (māla' bihā), she drives him crazy, he wastes away (mitmumi), she is killing him (qatlatnī), he is dying for her (muta 'alik). In anti-Islamic Arabic poetry, especially in one of the Imru'l-Qays b. H'ujr al-Kindî's Mu'allaqâ, he speaks about the woman like: 'The one who throws the arrows of death' (matānta lahalāk) (Berque, 1995, 24). In a Moorish poem the lover exclaims like:

Oh! My friends she knew to show herself so weak, fragile and vulnerable

Yet it was me she murdered without worrying about the loss.

The beloved woman is an enchantress who has 'tied [the man's] head' (marbūt $r a \overline{s i}$ ). The expression ' $r b \bar{t} t r \bar{a} s$ ' is generally used for lost cattle which, when found, must be immobilized with a magic spell (hijāb). This phrase, which belongs to the pastoral register, is used in matters of love to evoke the apathy of the lover bewitched by his beloved. And if the beloved woman's presence makes him suffer, her absence is far more painful. Today in Mauritania young people use an expression derived from French, fanatique, which refers to obsession and madness: 'You have made me fanatic about you' (fanatisaytini).

Far from hiding his flame, the lover tries to inspire the same passion in the woman by revealing it through his poetry in an attempt to disturb her through the expression of his feelings. It is not until the woman is touched by the man's vibrant appeal that she can give him her favours in response to this love. The lover's tears are intended for the one who causes them, with the intention that she will soothe them. In love poetry the woman is often called 'the reason for my sorrow' (sabab at-tulāh), or 'the reason for my death' (sabab qatlī). The pain of love is known in Hassäniyya as saqam, a classic Arabic term that refers to physical disease. This kind of love is close to the pharmakon (Derrida, 2006) which is the cause of the pain and also its remedy.

The lover's figure is a feminized figure, because he no can longer control himself and is subject to a passion that is annihilating him. Paradoxically, a man whose virility is characterized by self-control can be nevertheless possessed by passion, because for a man, being in the grip of such agony and confessing it to the one who has caused such disorder is the unavoidable preliminary step to the conquest of his beloved. The lover occupies a feminized position as a victim of passion; he seems to have lost the self-control expected of men, and furthermore his submissive attitude towards the object of his love testifies that he is in a situation of dependency, which among Moors and in other societies is usually characteristic of the feminine position. More generally, the feminine position is a fundamental characteristic of a person in a state of passion.

Thus, he has to show himself to be both extremely patient towards the woman he loves as well as profoundly disturbed. However, even when the man is in this state in the seduction phase, marked negatively with passivity and suffering, it is only a

\footnotetext{
${ }^{6}$ On the symbolic meaning of the heart in Arabic and in Islam, see Corinne Fortier (2007: 17). About the memorization process of the Koran in Moorish society related to the heart, see Corinne Fortier (2016a).
} 
temporary situation that represents minor harm on the way to conquering the woman and gaining a dominant position over other men.

From this perspective, poetry, which until recently was exclusively a masculine domain among Moors, constitutes a weapon of choice in the same way that it was a weapon for troubadours in the Medieval West (Roubaud, 1971). Like courteous love, the means used to conquer the woman are similar to techniques of hunting and borrow their vocabulary from warriors and hunters' lexicons.

\subsection{Secret Visits}

A man who, after a hard fight, wins a girl's favour at a night assembly continues to show her his affection by trying to meet her privately. Among Moors, especially in the desert, moments of intimacy between young people of the opposite sex are rare. It is only at night, when the woman's parents are sleeping, that the young man can try to approach her more closely. The clandestine character of these night visits appears in the term used in this context, which is directly related to the notion of 'secret' (sarriyya). By making this visit, which is attended by many risks, the young man shows his beloved that he is ready to die for her.

In the past, young men might travel very long distances to join their beloved. If a man owned a camel he would harness it in the middle of the night in such a way that the camel could not grunt, so that he could travel unnoticed. If he was too young to own a camel he travelled on foot, and moving forward in total darkness he risked getting bitten by a scorpion or a snake. Having arrived at the woman's encampment, the visitor would make sure her parents were sleeping. When he had entered the tent he would awake his beloved by gently pinching her nose.

Then they would converse in low voices. This act of conversing with people of the opposite sex is connected in thought and vocabulary to the act of making love. Thus the term most usually employed to designate intimacy between a man and a woman is titwannas, which means 'talking with,' from which the word for lover, wanīs, and mistress, wanīsa, are derived. In this Muslim society where the prohibition against men and women touching each other is important, conversation between lovers is laden with carnal overtones, close to Roland Barthes' (1977, 87) description:

The language is a skin: I rub my language against the other.

It is as if I had words by way of fingers, or fingers at the end of my words.

The young man would lie down behind the girl, who would turn her back on her parents so that they would not perceive the visitor if they woke up. He might be cautious enough to prefer to court her through the thin fabric enclosing the back of the tent (ukhar kurar). Seeking her company was perilous, because if he was discovered her father would not hesitate to chase him away with a stick or a rifle. 
The visit could go on until late, and the lover would have to fight sleep so as not to be found asleep beside the girl. He would leave as discreetly as he had come to be back in his own encampment before dawn in order not to be discovered. The night visit was a test for the lover who, having defied the dangers of the desert (scorpions, snakes, thorns and cold) and overcome the fear of divine punishment for illicit contact between unmarried men and women, exposed himself to the risk of being discovered. These dangers were the price he had to pay in order to join his beloved. By this visit marked out by risks, he showed his beloved that he was capable of dying for her. Moreover, such proof of love was also an initiatory test whereby the young man proved his bravery to the woman he loved on the one hand, and to friends of his own age on the other (Fortier, 2003). After this visit he would inform his friends in great detail about his perilous adventures.

One of young men's favourite pastimes is hunting women in the evenings. This practice is legitimized by the common assertion that 'a young man is always in search of an adventure'. Young men roam through the city in groups, often by car, in search of women. New expressions inspired by the French language have appeared: 'tant $\vec{\imath}$ ', from tenter, to try, and ' $t d r \bar{a} g \vec{\imath}$ ', from draguer, to hit on someone. This new behaviour is typical of city-dwellers, especially in the capital. In Nouakchott one type of entertainment consists of going out of the city at the weekend (Thursday and Friday), to drink milk, hunt bustards, and conquer country girls, whom which these rich city-dwellers describe as 'good meat'. The men arrive at isolated encampments with their big cars and their expensive presents from the city to try to impress the 'country women' and seduce them.

\subsection{The Expenses of Love}

Young men who visited their beloved in the night generally brought her a present, for example a perfume bottle (bush min musk). Today, young men offer women a henna (hanna) or hairstyling (zhvir) session, or another object of feminine finery such as a veil, a handbag or a jewel. These presents are given to pay tribute to the woman and her beauty, and as such are called 'gifts to beauty' (hadiyāt al-jamāl). They are necessary proofs of love, and a man trying to seduce a woman cannot avoid making these offerings. The lover has to show himself generous to the woman he loves, sparing no effort, because spending his time and money without stint is like giving himself to her. In the love relationship the man must show his generosity, which is part of his honour. This poem gives an account of the necessary spending for love:

I want to be with her/I do not wish to distance myself from her,

I saw her/yesterday while I was crossing a deserted place,

For her, I lost/so much wealth, oh misfortune,

For her, I lost/so many quatrains ( givān) and poems (tal'a).

Women are not expected to show gratitude when accepting poems and presents. For example, a poet deplores the losses provoked by an unhappy love affair, due in 
particular to the gifts $\left(\operatorname{tam}^{\prime} a\right)$ given to griots to sing the poems he had composed for her to his beloved. However, in spite of the poet's bitterness about the disproportion between what he says he gave her and what he has received from her, he tells us that he continues to love her and still dedicates his poems to her.

This sort of feeling (Fortier, 2004b) resembles the joi of troubadours, which combines enjoyment, suffering and the game (Roubaud, 1994). Likewise, the woman's refusals, far from repelling the lover, arouse his desire. It is considered part of the game of seduction and explains why women are affectionately called 'traitress' (khawwāna) in some poems, an expression found in Baudelaire's poem: 'The invitation to travel' $(1975,53)$ addressed to Mrs. Sabatier: 'of your treacherous eyes'.

Furthermore, the lover's disappointment not only shows his beloved's indifference but also reveals the level of his love, as this Moorish poem shows:

You never gave me even a little of your love, /a little of your laugh

But someone who has never seen you angry/doesn't know the taste of love.

The poems, like the numerous presents and services offered to the beloved woman, thus all participate in what Roland Barthes $(1977,99)$ broadly calls 'the expenses of love'.

\subsection{The Objets of Love}

Through these ordeals young men learn to control their desires. As the medieval cortezia rules characterized by secrecy, patience and measure (De Rougemont, 1972, 79), the woman's caprice is answered by the constancy of the lover. Like in the medieval fin amor (Baladier, 1999, 82), Moorish women give themselves gradually to their lovers to test them, and the man is called a 'sufferer' (sofridor) (Dragonetti, 1960: 78). Likewise, Moorish women grant concessions to men only progressively: at first a smile, then a wink, and so on... To test their pretenders' patience (sabr), women refuse any physical contact for a long time. However, they sometimes let the lover steal an object that she is carrying. The lover preserves this object affectedly next to his heart, putting it in the pocket of his boubou $\left(\operatorname{dar}^{c} a\right)^{7}{ }^{7}$

The stolen object is archetypally a toothpick (miswāk), an erotic object because the woman has held it between her lips and chewed it sensually. Through the mediation of this metonymical object, the lover kisses her indirectly. Other objects that she has touched can play the same mediating role, such as a rosary (tasbīh), a ring (khatma), or a watch (waqqāta), which the lover wears to be closer to the beloved. This 'souvenir' - the French word has been borrowed in Hassāniyya - also supports him in the absence of the beloved, sometimes even after his death, as

\footnotetext{
${ }^{7}$ The boubou refers in French to the long loose-fitting garment worn by men in Mauritania.
} 
described in a poem where the lover remains faithful to the woman he loved even in the grave, keeping objects that she had carried with him in the tomb.

The fetish object represents not only the beloved woman but also the love relationship itself. By showing it, the young man makes the relationship public. More recently a photograph of the beloved has fulfilled this role; the lover carries it in the pocket of his boubou and shows it proudly to his friends. Women are the object of men's desire; a desire that they learn to discipline through the courtship itself. Proof of love is also proof of virility.

\subsubsection{Inaccessible Married Women}

In Moorish society seduction aims for the conquest of the desired woman, who is divorced (Fortier, 2012, 2016b) or even married. The desire for these categories of women reveals the challenge that motivates such courtship. Seduction is a test for the man, who must show his virile virtues by being patient, generous, attentive and brave. Like medieval Western courtly love, the supreme test is to win the heart of a married woman, who is by definition inaccessible. The transgression is social but also religious, as according to the Koran (IV, 24, transl. Arberry, 1980), the wife is a forbidden woman. A man's desire for a married woman is enhanced by the illicit character of the relationship. The furtive night meeting suits this type of relationship, which is marked with the seal of secrecy. The man's visit to his beloved is not without risk, and the transgression is always accompanied by fear. The attractiveness of this transgression motivates men to try and visit married women frequently.

The clandestine character of the extramarital relationship forces the lover to use subterfuge to meet the woman. The husband and the lover have to be, according to the Hassāniyya expression, 'like cow's horns', suggesting that they must not meet. The lover's ingenuity consists of seizing convenient moments when the husband is away. Generally there are many occasions to visit her, the husband being absent from home most of the time; during the day he attends to his work taking care of his cattle, his shop, or his office, and in the evening he usually meets up with friends.

\subsubsection{Husbands Who Are Not Jealous}

It is believed that Moorish husbands grant a certain amount of freedom to their wives to receive men in their tents or houses and to circulate in the public sphere as they wish. Husbands consider their wives precious goods which grant them social prestige, thanks to their power of seduction. Often flattered by the idea that they have married a woman whom numerous men desire, men allow their wives to play their mundane role by receiving admirers at home. A husband should not be jealous of this assembly of lovers as long as he keeps his exclusive right to the possession of 
his wife. She should grant only 'a jaw' to lovers, meaning a polite smile and a friendly word.

The Arabic traveller Ibn Battûta (1982, 403), describing the life of people in the old city of Walata in the fourteenth century, was surprised by the freedom in the Moors' customs:

In this country, the women take friends and companions among foreign and unrelated men. The men, for their part, have partners whom they take among their non-relatives. It often happens that a man enters his home and he finds his wife with her companion: he does not disapprove of this conduct, and does not take offence at it.

If a wife's extramarital affairs are discreet, the husband should not try to catch her out. Jealousy is considered a base feeling that a married man should not show, because the nobility of his behaviour requires that he controls his emotions. In such a situation, again men must visit their beloved furtively: everything is possible as long as it remains discreet.

From this viewpoint, the fault is less adultery than a lack of discretion when committing it, so that when a husband surprises his wife in an unacceptable situation he is forced to defend his honour. He chases away the lover with his rifle or with insults, and then has an argument with his wife. It is one of the few reasons that men beat their wives. However, although adultery is condemned, violence towards a woman is condemned even more. A woman who suffers from such violence may dramatize her misfortune by shouting and tearing her clothes to reverse the opprobrium to her husband.

\subsubsection{Jealous Wives}

Men are more actively involved in extramarital relationships than women. Adultery is more socially acceptable when committed by men, as it fits their supposed need for conquest (Fortier, 2013a). Moorish women compare men with camels who eat the leaves of a tree while casting their eyes over the foliage of another branch: always in search of a new affair.

However, when a Moorish woman suspects her husband of infidelity, as a sign of her disapproval she may return to her parents' home (Fortier, 2011). Some women leave their husband with their children after learning that he has composed a quatrain about his love for another woman. In such cases the husband usually sends a delegation of respectable men to his wife to ask her to forgive his faults and come back. Furthermore, to redeem himself and as proof of his love, he should offer her valuable presents.

Among Moors, as in many societies, the marital relationship has a main purpose: the creation of a family. The wife has several duties towards her husband, one of which is to give him children. For a woman, extramarital relationships seek not procreation but pleasure-pleasure which can also be pursued in the marital relationship. In parallel, for a man the extramarital relationship aims to secure the desired 
woman, challenging his rivals and asserting his virile qualities. Some husbands can gain prestige from having an attractive wife, but this does not necessarily suffice to calm their thirst for conquest outside the marital relationship. A wife gives her husband progeny, enabling him to fulfil his social role as a father. A mistress, on the other hand, stimulates his taste for a challenge because she does not belong to him legally. Whether a mistress or a wife, the woman provides the man with the opportunity to demonstrate his virile qualities, in each case related to conquest and to fathering. ${ }^{8}$

\subsection{Conclusion: Masculine Desire}

For Moors, seduction and poems aim at the conquest of the desired woman. For a man, conquering the courted woman is also a way of defying his rivals. This approach is similar to what Sigmund Freud $(1987,49)$ describes as the conditions of masculine desire in certain cases:

[...] the lover shows no desire to possess the woman for himself only, and seems to be fully at ease in the triangular relation [with other men].

It shows that Sigmund Freud analysis on this matter is not only relevant from an occidental point of view but for an universal one.

Women are assets to what is in fact masculine rivalry. The lover's rivalry concerns all the woman' other suitors as if they themselves were objects of desire. In this respect, Freud showed that sexual rivalry implies more interest in the rival than in the woman, an observation confirmed by Roland Barthes (1977: 80):

Jealousy is an equation involving three permutable (indeterminable) terms: one is always jealous of two persons at once: I am jealous of the one I love and of the one who loves the one I love. The odiosamato (as the Italians call the 'rival') is also loved by me: he interests me, intrigues me, appeals to me.

However, such a feeling is inadmissible because it implies that other men are thought of as objects of desire. Thus, men express themselves through the fight for a woman, who is presented as the sole target of their desire.

In the game of love women are seen as objects of desire for men and their own desires are never acknowledged. The woman who is courted draws some material advantage from seduction relationships, knowing that most of these will be temporary. The man supports the cost because it flatters his virility, of which generosity is part. It also stimulates his taste for conquest associated with challenge. A woman has a more difficult game to play to win respect, because by immediately granting her favours she may appear to be too easy, endangering her dignity, which is closely socially related to modesty. She must defend her image of the inaccessible woman

\footnotetext{
${ }^{8}$ On the importance of becoming a father in this and other societies, see Corinne Fortier (2013b, 2017a).
} 
who will admit the lover to intimacy with her only through patient effort and prodigality. His relationships with women reveal to the man what creates his virility: generosity, courage and self-control.

As in most societies, Moorish men are mainly the initiators of sexual relations, as if the free expression of their desire is authorized more than that of women. In this society sentimental and sexual attraction are a man's privilege. The right to express one's desires is an element of domination in so far as women are deprived of it. The fact that men are considered the subjects of desire and women its object is a major cross-cultural element which ensures men's appropriation of women's bodies and structures relations between people of the opposite sex. ${ }^{9}$

\section{References}

Abu-Lughod, L. (1986). Veiled sentiments: Honor and poetry in a Bedouin society. Berkeley: University of California Press.

Ahearn, L.-M. (2003). Writing desire in Nepali love letters. Language \& Communication, 23(2), $107-122$.

Ahearn, L.-M. (2004). Literacy, power, and agency: Love letters and development in Nepal. Language \& Education, 18(4), 305-316.

Arberry, A. J. (1980). The Koran interpreted (Trans.) London: George Allen/Unwin.

Baladier, C. (1999). Eros au Moyen Âge. Paris: Cerf.

Barthes, R. (1977). Fragments d'un discours amoureux. Paris: Seuil.

Bațuta, I. (1982). Voyages. t. 3, Inde, Extrême Orient, Espagne et Soudan, 1858 (Le voyage au Soudan) (Vol. 5, pp. 393-446). Paris: La Découverte.

Baudelaire, C. (1975). Oeuvres Complètes, t.1. Paris: La Pléiade.

Berque, J. (1995). Transl., Les dix grandes odes arabes de l'anté-islam. Paris: Actes Sud/Sindbad (La bibliothèque arabe).

Blachère, R. (1975). Analecta. Damas: Institut Français de Damas.

Cole, J., \& Lynn, T. (2009). Love in Africa. Chicago: University of Chicago Press.

Comte Sponville, A. (1995). Petit traité des grandes vertus. Paris: PUF (Perspectives critiques).

De Rougemont, D. (1972). L'amour et l'Occident. Paris: Plon (10/18).

Demeuldre, M. (2004). Introduction. In M. Demeuldre (Ed.), Sentiments doux-amers dans les musiques du monde. Délectations moroses dans les blues, fado, tango, flamenco, rebetico, p'ansori, ghazal (pp. 5-23). Paris: L'Harmattan (Logiques sociales, musique et champ social).

Derrida, J. (2006). La pharmacie de Platon. Paris: Flammarion-Gallimard (Poche).

Dictionnaire le petit Robert. (1990). Dictionnaire alphabétique et analogique de la langue française, rédaction dirigée par A Rey \& Rey-Debove, J. Paris: Dictionnaires Le Robert.

Dragonetti, R. (1960). La technique poétique des trouvères dans la chanson courtoise. Bruges: De Tempel.

Duby, G. (1981). Le chevalier, la femme et le prêtre. Paris: Hachette.

Duby, G. (1988). Mâle Moyen Âge. De l'amour et autres essais. Paris: Flammarion.

Farès, B. (1932). L'Honneur chez les Arabes avant l'Islam. Paris: Maisonneuve.

Fortier, C. (1998). Le corps comme mémoire: Du giron maternel à la férule du maitre coranique. Journal des Africanistes, 68(1-2), 199-223.

\footnotetext{
${ }^{9}$ On this subject, see also Corinne Fortier (2019).
} 
Fortier, C. (2003). Épreuves d'amour en Mauritanie. L'Autre. Cliniques, cultures et sociétés, 4(2), 239-252.

Fortier, C. (2004a). Séduction, jalousie et défi entre hommes: Chorégraphie des affects et des corps dans la société maure. In F. Héritier \& M. Xanthakou (Eds.), Corps et affects (pp. 237-254). Paris: Odile Jacob.

Fortier, C. (2004b). "Ô langoureuses douleurs de l'amour". Poétique du désir en Mauritanie. In M. Demeuldre (Ed.), Sentiments doux-amers dans les musiques du monde (pp. 15-25). Paris: L'Harmattan.

Fortier, C. (2007). Blood, sperm and the embryo in Sunni Islam and in Mauritania: Milk kinship, descent and medically assisted procreation. Body and Society, 13(3), 15-36.

Fortier, C. (2011). Women and men put Islamic law to their own use: Monogamy versus secret marriage in Mauritania. In M. Badran (Ed.), Gender and Islam in Africa: Rights, sexuality and law (pp. 213-232). Washington: Woodrow Wilson Press.

Fortier, C. (2012). The right to divorce for women $\left(\mathrm{khul}^{\circ}\right)$ in Islam: Comparative practices in Mauritania and Egypt. In R. Mehdi, W. Menski, \& J. S. Nielsen (Eds.), Interpreting divorce laws in Islam (pp. 155-175). Copenhagen: DJOF Publishing.

Fortier, C. (2013a). Les ruses de la paternité en islam malékite: L'adultère dans la société maure de Mauritanie. In A.-M. Moulin (Ed.), Islam et révolutions médicales. Le labyrinthe du corps (pp. 157-181). IRD/Karthala: Marseille/Paris.

Fortier, C. (2013b). Genre, sexualité et techniques reproductives en islam. In F. Rochefort \& M. E. Sanna (Eds.), Normes religieuses et genre. Mutations, Résistances et Reconfigurations XIXè XXI

Fortier, C. (2016a). Orality and the transmission of Qur'anic knowledge. In R. G. Launay (Ed.), Writing boards and blackboards: Islamic education in Africa (pp. 62-78). Bloomington \& Indianopolis: Indiana University Press.

Fortier, C. (2016b). Divorce and custody. Contemporary practices: Mauritania and Egypt. In J. Suad (Ed.), Encyclopedia of women and Islamic cultures. Leiden: Brill. Accessed August 8, 2018, from https://doi.org/10.1163/1872-5309_ewic_COM_00203008.

Fortier, C. (2017a). Les procréations médicalement assistées en contexte musulman au prisme du genre. In C. Fortier \& S. Monqid (Eds.), Corps des femmes et espaces genrés arabo-musulmans (pp. 241-256). Paris: Karthala.

Fortier, C. (2017b). Les maux du médecin: savoir, expérience et dévouement. In V. Barras, C. Fortier, B. Graz, \& A.-M. Moulin (Eds.), Le Recueil des vertus de la médecine ancienne de Maqâri. La médecine gréco-arabe en Mauritanie contemporaine (pp. 25-36). Lausanne: BHMS éditions (Sources en perspective).

Fortier, C. (2017c). Derrière le 'voile islamique', de multiples visages. Voile, harem, chevelure: identité, genre et colonialisme. In A. Castaing \& É. Gaden (Eds.), Écrire et penser le genre en contextes postcoloniaux (Comparatisme et société) (pp. 233-258). Berne: Peter Lang.

Fortier, C. (2018a). The expences of love: Seduction, poetry and jealousy in Mauritania. In C. Fortier, A. Kreil, \& I. Maffi (Eds.), Reinventing love? Gender, intimacy and romance in the Arab world (Middle East, social and cultural studies) (pp. 47-69). Berne: Peter Lang.

Fortier, C. (2018b). Milk, breast. In H. Callan (Ed.), The international encyclopedia of anthropology. Oxford: John Wiley. https://doi.org/10.1002/9781118924396.wbiea1433. https:// onlinelibrary.wiley.com/doi/abs/10.1002/9781118924396.wbiea1433.

Fortier, C. (2019). Sexualities: Transexualities: Middle East, North Africa, West Africa. In S. Joseph (Ed.), Encyclopedia of women and Islamic cultures (EWIC), Supplement 20. Leiden: Brill. https://doi.org/10.1163/1872-5309_ewic_COM_002185.

Fortier, C., Kreil, A., \& Maffi, I. (2016). The trouble of love in the Arab world: Romance, marriage, and the shapping of intimate lives. The Arab Studies Journal, Special Section: Love in the Arab World, 24(2), 96-101. 
Fortier, C., Kreil, A., \& Maffi, I. (2018). Introduction. In C. Fortier, A. Kreil, \& I. Maffi (Eds.), Reinventing love? Gender, intimacy and romance in the Arab world (Middle East, social and cultural studies) (pp. 9-32). Berne: Peter Lang.

Freud, S. (1987). Trois essais sur la théorie sexuelle. Paris: Gallimard.

Giddens, A. (1992). The transformation of intimacy: Sexuality, love and eroticism in modern societies. Cambridge: Polity Press.

Hirsch, J. S., \& Wardlow, H. (Eds.). (2006). Modern loves: The anthropology of romantic courtship \& companionate marriage. Ann Arbor: University of Michigan Press.

Illouz, E. (1997). Consuming the romantic utopia: Love and the cultural contradictions of capitalism. Berkeley: University of California Press.

Jankowiak, W. R., \& Fischer, E. F. (1992). A cross-cultural perspective on romantic love. Ethnology, 31(2), 149-155.

Jankowiak, W. R., Volsche, S. L., \& Garcia, J. R. (2015). Is the romantic-sexual kiss a near human universal? American Anthropologist, 117(3), 535-539.

Lavaud, R., \& Nelli, R. (2000). Les Troubadours. T. II: L'œuvre poétique. Paris: Desclée de Brouwer.

Lindholm, C. (1988). Lovers and leaders: A comparison of social and psychological models of romance and charisma. Social Science Information, 27(1), 3-45.

Lindholm, C. (2006). Romantic love and anthropology. Etnofoor, 19(1), 5-21.

Lipset, D. (2004). Modernity without romance? Masculinity and desire in courtship stories told by young Papua new Guinean men. American Ethnologist, 31(2), 205-224.

Lutz, C., \& Abu-Lughod, L. (1990). Language and the politics of emotion. Cambridge/Paris: Cambridge University Press/Éditions de la Maison des sciences de l'Homme.

Lutz, C., \& White, G. (1986). The anthropology of emotions. Annual Review of Anthropology, 15 (1), 405-436.

Mead, M. (1966). Coming of age in Samoa. A psychological study of primitive youth for Western civilisation. Harmondsworth: Penguin.

Ould Ahmed Salem, Z. (2013). Prêcher dans le désert. Paris: Karthala.

Padilla, M. (Ed.). (2007). Love and globalization: Transformations of intimacy in the contemporary world. Nashville, TN: Vanderbilt University Press.

Pettier, J. B. (2016). The affective scope: Entering China's urban moral and economic world through its emotional disturbances. Anthropology of Consciousness, 27(1), 75-96.

Roubaud, J. (1971). Les troubadours. Anthologie bilingue. Paris: Seghers.

Roubaud, J. (1994). La Fleur inverse: L'art des troubadours. Paris: Les Belles Lettres.

Stacey, J. (2011). Unhitched: Love, marriage, and family values from West Hollywood to Western China. New York: New York University Press.

Taleb-Khyar, M. B. (2001). La Mauritanie: le pays au million de poètes. Paris: L'Harmattan.

Tcherkézoff, S. (2004). 'First contacts' in Polynesia: The Samoan case (1722-1848). Western misunderstandings about sexuality and divinity. Canberra/Christchurch: Macmillan Brown Centre for Pacific Studies, The Journal of Pacific History Monographs.

Vadet, J.-C. (1968). La futuwwa, morale professionnelle ou morale mystique. Revue des études islamiques, 66, 57-90.

Von Hammer-Purgstall, J. (1849). La Chevalerie des Arabes antérieure à celle d'Europe: De l'influence de la première sur la seconde (pp. 4-14). Janvier: Journal Asiatique.

Wettstein, J. (1945). Mezura. L'idéal des troubadours: Son essence et ses aspects. Genève: Slatkine Reprints.

Zakeri, M. (1996). Muslim 'chivalry' at the time of the crusaders. Hallesche Beiträge zur Orientwissenschaft, 22, 29-50.

Zavoretti, R. (2013). Be my valentine: Bouquets, marriage, and middle class hegemony in urban China. Halle/Saale: Max Planck Institute for Social Anthropology. 
Corinne Fortier is a cultural anthropologist and a researcher at the French National Center of Scientific Research (CNRS). She is also a member of the Social Anthropology Lab (LAS) from the Collège de France (CNRS-EHESS-Collège de France-PSL University, Paris). Bronze Medal 2005 of the French National Center of Scientific Research (CNRS). She conducted research in Mauritania and in Egypt as well as on Islamic scriptural sources related to gender, body, love, and family law. 